\title{
Teachers Readiness in Using ICT in the Classroom: The Case of a Developing Country
}

\author{
Nomsa Mndzebele
}

\begin{abstract}
The aim of the study is to present a review of the teachers' readiness of teaching ICT as a subject, integrating ICT to the other subjects in Swaziland, taking into consideration the challenges encountered in the classrooms. A quantitative research design was used through a questionnaire to collect data from a sample of schools. Systematic sampling was done on the schools in terms of region, location (urban/rural) and type of school (government, mission/church or community). A qualitative research design was also used to collect data through interviews in all teacher education institutions in the country. The study reveals that the Ministry of education has to build an education and training system that will support the teaching ICT as a subject and ICT integration in teaching and learning.
\end{abstract}

Index Terms - Information communication technology, integration, teachers and schools.

\section{INTRODUCTION}

In Africa, the introduction of computers in primary and secondary schools is a recent phenomenon [1]. For Africa to compete in the global economic environment, a highly skilled and educated workforce with aptitudes and skills in the application of Information and Communication Technology (ICT) is essential [2]. This calls for policies that promote broad access to skills and competencies, and especially the capability to be ICT literate [3]. This can be achieved by providing broad-based formal education, establishing incentives for teachers and individuals to engage in continuous training [4]. It is important that all education sectors understand the benefits of investing in ICT and in the infrastructure required for introducing ICT in education. There is a need for government to partner with the private sector for resource mobilisation to fund the use of ICT in education [3].

Like other developing countries, Swaziland faces challenges in achieving the Millennium Development Goals and Education For All. In order to widen access to quality education, Swaziland has come up with policies and strategies in a bid to harness the role of technology towards building a knowledge-based society [5], [6]. Swaziland has formulated an education sector implementation plan on the use of technology to deliver electronic educational tools, assessment and collaborative learning. To facilitate these plans, barriers need to be identified so that they may be

Manuscript received March 27, 2013; revised June 2, 2013.

Nomsa Mndzebele is with the Faculty of Commerce, University of Swaziland, Kwaluseni, Swaziland (e-mail: nomsa@uniswa.sz). overcome. There are a number of barriers that still exist in practice in the schools. In 2011 and 2012 there were 146 schools in the country that had computers, $39 \%$ of the schools were in the rural areas and $19 \%$ in the urban ones [7]. The MoE ICT policy explicitly states that the emphasis on ICT should be in the rural areas. Of the 146 schools only 38 wrote a recognized exam. The other schools are not yet ready to write this type of exam. The quality and numbers of ICT facilities that schools have managed to secure through different means vary: for example, some schools have received refurbished donated computers which require a lot of maintenance. The introduction of ICT in the schools was mainly meant to give learners basic ICT literacy skills [8].

The aim of this study is to present a review of the teachers' readiness of teaching ICT as a subject, integrating ICT to the other subjects in Swaziland, taking into consideration the challenges encountered in the classrooms. It is hoped that the paper will be useful to policy makers, educators, and other decision-makers who are directly involved in introducing ICT in the schools in other developing countries.

Just like any project introducing technology in the schools requires an implementation plan. The plan should be produced not for the sole purpose of putting technology in the classroom but to reflect the real needs of schools so that the introduced technology can be effective. Lack of funding and inadequate planning has been seen as two major obstacles to the implementation of the ICT project [9]. Technology integration has suffered failure because of little or no professional development initiatives, the absence of national policies on ICT education and the lack of community involvement [10], [11].

\section{Methodology}

A quantitative and qualitative research design has been used for the study. The purpose of the study is to find out if teachers in schools are ready to teach ICT as a subject in the schools and integrate ICT to the other subjects in the schools. An assessment of the current situation in the country was necessary and takes into considerations the challenges that are encountered in the classroom, and recommend a program for the training of teachers.

The study was descriptive that consisted of phase 1 and 2 . Phase 1 was a close ended questionnaire. The schools were drawn from the database of the MOE. The target population was schools that have computers so as to be able to assess the current situation in the classrooms. Systematic sampling was done on each of the schools from each of the four regions in the country. The questionnaires were administered to 42 high schools with ICT out of 146 high schools (Ministry school 
list as of March 2012) which were selected in terms of region, location (urban or rural) and type of school (government owned, mission owned, or community school). All the questionnaires were received from the participants. The purpose of phase 1 was to get the current challenges faced by the teachers in the classroom in teaching ICT and integrating ICT in the classroom.

Phase 2 of the survey was interviews with all the Teacher education institutions in the country. Faculty of Education and other relevant departments (those that offer education) in the different institutions were interviewed. Principals and deputy principals of the schools visited in the four regions were also interviewed. Phase 2 of the study was to find out the challenges faced by the institutions in teaching ICT in the institutions.

\section{ICT AS A TEACHING SUbJECT IN THE SCHOOLS}

MoE does not have a standard curriculum; each school has to rely on its own resourcefulness. The schools that offer ICT as a subject in grade 12 have to use the UK grade 12 syllabus. One of the probable reasons why some schools are not writing the International General Certificate of Secondary Education in ICT (IGCSE, a grade 12 exam set and marked in UK) exam is that there are very few qualified ICT teachers in the schools and government has not been creating positions for teachers because of the economic crisis in the country. Most schools have engaged teachers from private tertiary colleges which are not accredited by the Ministry of Education. A study done in 2012 with a sample of 42 schools, in both urban and rural areas, that have ICT, showed that $32 \%$ of the teachers employed by government teach ICT. Amongst the $32 \%$ are the teachers who did a computer science course and are looking for jobs in the industry.

Table I shows the performance of the IGCSE in Swaziland compared to the world's IGCSE figures. The years when there were computer sciences teachers can be seen by the results: the performance is much better, but immediately those teachers leave the results are poor.

The Ministry of Education has drafted the ICT policy [12], [13] and is encouraging schools to teach ICT. However, there is no Teacher Training College in the country that teaches teachers with a degree in ICT. The computer science department trains for industry, not for the teaching profession. $34 \%$ of the teachers teaching ICT are holders of a Bachelor's Degree employed for other subjects such as mathematics, science, business, accounting, geography and agriculture, etc. These teachers have their different teaching subjects for which they were trained at the University. These teachers are expected to teach ICT for the IGSCE exam and yet they do not know the content like in their areas of specialization. What these teachers know about computing is what they learned at the University to help them get around with their work, not to teach [11]. Teachers's knowledge includes knowledge of the subject, teaching methods, classroom management strategies and how to teach specific content to specific learners in specific contexts. The present ICT teachers in Swaziland do not have any of these [11]. Basically ICT is treated like a subject that can be taught by anybody who can use a computer as if there is no content.
TABLE I: PERCENTAGE OF CANDIDATES ACHIEVING “G” OR ABOVE IN ICT

\begin{tabular}{|l|l|l|l|l|l|}
\hline & 2007 & 2008 & 2009 & 2010 & 2011 \\
\hline World Totals \% & 97.7 & 94.3 & 97.2 & 96.5 & 95.4 \\
\hline Swaziland \% & 70 & 85.3 & 77.3 & 79.3 & 63.8 \\
\hline
\end{tabular}

Source: Report MoE/Jica October 2012

[14] state that in Mauritius teachers completed their ICT training and were posted to primary schools that had no computers and the result was frustration amongst the ICT teachers and a sense of disillusionment in the nation. However, in Swaziland schools have computers but they do not have ICT teachers.

\section{ICT INTEGRATION WITH THE OTHER SUBJECTS}

ICT is supposed to improve the internal efficiency of educational systems, enhance the quality of education for a technology-driven marketplace. Technology can foster more interest in learning on the part of students if it is properly used and teachers can use it in the instruction of their respective subjects. Technology can prepare students on how to integrate the world of work and competition tomorrow.

The Swaziland Computer Education Trust (CET) was set up in 1999 "with funding from private business sources within Swaziland to address the poverty of technical education in the country" [15]. The computers were intended for use across the school curriculum.

Technology integration requires that pre- and in-service teachers understand the technology tools themselves and know which tools will make learning easier for the students [16]. [17] state that, if teachers are going to prepare the students to be technologically capable, they need to have the basic technology, skills, know-how, on how to use technology, hardware and software, otherwise teachers will have problems in using the technology effectively in the classroom.

Teachers expected to teach basic skills are science, agriculture and accounting teachers, Pre-service teachers know very little about effective use of technology in education. [14] found that institutions of higher learning do not prepare teachers to work in a technology-enriched classroom. They also found that, despite the fact that many pre-service teachers were exposed to instructional technology coursework, it was not linked to pedagogy or their field experiences.

Pre-service teachers must be taught using technology as well as being exposed to ways in which technology can be used in their classes if technology is to reform the education process [17]. Teacher training is critical, teachers must feel prepared to use technology [18], [19] if they are to use it in their classes with their students. Technology should be integrated in teacher preparation programs so that teachers can see technology in use [18], [20]. This will in turn influence the way they use technology when they become field teachers. The task of preparing teachers to use technology should not be left to their post-university experiences, it has to begin with the training they receive in their college experience, otherwise the teachers will not 
accept the technology [18].

There are three Teacher Training Colleges accredited by the Ministry of Education in the country. Unfortunately there is a shortage of ICT lecturers in the colleges. The college lecturers need to be taught how to use technology in the classroom so that they can pass on the knowledge. The in-service training has to start with the lecturers in the colleges.

The teachers mentioned that they would be willing to come for in-service training at the University of Swaziland to get basic skills and learn how to use the tools in the schools [3]. Knowing how to use the tools is foundation. Teaching with technology requires the teachers to expand their knowledge of pedagogical practices across multiple aspects of the planning, implementation and evaluation processes. Lack of these technology-related management skills can hinder technology integration [21]. If properly integrated, ICT has the potential to promote technology in education, but it should not be considered as a replacement for face-to-face instruction, rather as a support to attain objectives that have not been attained efficiently otherwise.

Reference [22] state that there are three stakeholders in the learning of ICT and these are teachers, school administration and parents. He further mentions that these three are the ones that drive the wheel that drives the ICT integration engine, and their involvement at the outset cannot be underestimated. Failing to take this into account may result in either slow or no integration. [23] states that many countries do not have financial means to support technology integration in schools. Where there are computers, they are insufficient for the schools; some classes are very large [24]. Most of the computers in the schools in Swaziland at present are a result of donations or projects from private companies or foreign donors. In the case of projects the problem comes in when the project comes to an end and government has to take over. The schools have realized that there is no funding coming from government to support the maintenance of the computers, Internet and to pay the teachers, so the cost has been passed on to the parents.

\section{CONCLUSION}

It is therefore necessary that teacher education programs adequately prepare new teachers with skills and content necessary to teach ICT as a subject. Technology should be integrated in teacher preparation programs so that teachers can see technology in use and be taught how to teach the pedagogical methods that facilitate student learning in their classes.[25] warns against the danger of promising too much or ignoring the real limitations the country is faced with. Recommendations that are made on educational reform should be feasible, realistic and dependent on the political situations of a country.

The Ministry of Education needs to build an education and training system that will support ICT integration in teaching and learning. It also needs to encourage and support one of the institutions to have students majoring in ICT as a teaching subject. The system must build teacher confidence in the use of ICT. Teachers need to have access to in-service training on how to integrate ICT into teaching and learning. The Ministry should further encourage pre-service teacher training institutions to include basic computer literacy and basic ICT integration into their teaching and learning. The government can help by subsidizing the Internet services through Swaziland Post and Telecommunication (SPTC) which is owned by government. This would enable schools that cannot afford Internet to have access to e it. The parents could concentrate on the maintenance of computers than paying for the Internet.

\section{REFERENCES}

[1] S. H. Khan et al., "Barriers to the Introduction of ICT into Education in Developing Countries: The Example of Bangladesh," International Journal of Insertion, vol. 5, no. 2, ISSN: 1694-609X, 2012.

[2] K. A. Lawless and J. W. Pellegrino, "Professional development in integrating technology into teaching and learning: Knows, unknowns, and ways to pursue better questions and answers," Review of Educational Research, no. 77, pp. 575-614, 2007.

[3] Swaziland Government Ministry of Education and Training (MoET) In Corporation with Japan International Cooperation Agency (JICA) November, Current Situation and Challenges in Mathematics, Science and ICT Education at Secondary level and Teacher Education, 2012

[4] The Swaziland Education and Training Sector Policy, Mbabane Swaziland, April, 2011.

[5] A. Senteni, "Information and Communication Technology Integration and Developmental Intervention: Enabling knowledge creation and Capacity Building in Developing Countries' Organisations,' Educational Technology Research and Development, vol. 54, no. 3, pp. 300-311, 2006.

[6] Swaziland Government Ministry of Education and Training, Draft policy for Information and Communication Technology, July, 2010

[7] S. M. Tapan, "Using ICT in Teaching-Learning at the Polytechnic Institutes of Bangladesh: Constrains and Limitations," Teachers World-Journal of Education and Research, pp. 33-34/207-217, 2009.

[8] E. C. Papanastasiou, "Evaluating the Use of ICT in Education: Psychometric Properties of the Survey of Factors Affecting Teachers with Technology (SFA-T)," Education Tecnology \& Society, vol. 11, no. 1 , pp. $69-86$,

[9] I. Shafika, "ICT in Education in Swaziland; survey of ICT and Education in Africa," Swaziland Country Report, 2007.

[10] UNESCO, ICTs AND Education Indicators: (Suggested core indicators based on meta-analysis of selected International School Surveys), Communication Statistics Unit UUNESCO Institute for Statistics CP6128 Succursale Centraville Montreal H3C 3J7, Quebec, Canada, 2006.

[11] A. P. Gilakjani, "EFL Teachers Beliefs toward Using Computer Technology in English Language," Journal of Studies in Education, vol. 2 , no. 2 , pp. 62-86, 2012

[12] United Nations Development Programme, Mbabane, 2010.

[13] National Information and Communication Infrastructure Policies, Strategies and Plans, Implementation Plan 2012-2016.

[14] W. J. Pelgrum, "Obstacles to the Integration of ICT in Education: Results form a Worldwide Educational Assessment," Computers \& Education, no. 37, pp. 163-178, 2001.

[15] R. Snoeyink and P. Ertmer, "Trust into technology: how veteran teachers respond," Journal of educational technology systems, vol. 30, no. 1, pp. 85, 2001.

[16] M. Grazzi and S. Vergara, "ICT in developing countries: Are language barriers relevant? Evidence from Paraguay," Information and Economics and Policy, no. 24, pp. 161-171, 2012

[17] National Information and Communication Infrastructure (NICI Plan 2016) Implementation Plan 2012-2016.

[18] Educational Management Information Systems (EMIS), Swaziland Government Ministry for Education and Training, 2010.

[19] F. M. Ihmeideh, "Barriers to the Use of Technology in Jordanian Pre-school Settings, Technology," Pedagogy and Education, vol. 18, no. 3, pp. 325-341, 2009

[20] Y. Goktas, S. Yildirim, and Z. Yildirim, "Main Barriers and Possible Enablers of ICTs Integration into Pre-service Teacher Education Programs," Educational Technology \& Society, vol. 12, no. 1, pp. 193-204, 2009

[21] L. D. Rosen and M. M. Weil, "Computer Availability, Computer Experience, and Technophobia Among Public School Teachers," Computers in Human Behaviour, vol. 11, no. 1, pp. 9-31, 1995. 
[22] F. D. Davis, "Perceived Usefulness, Perceived Ease of Use, and User Acceptance of Information Technology," MIS Quarterly vol. 13, no. 3, pp. 319-339, 1989.

[23] K. C. Gray, "Teachers' perceptions of innovation adoption," Action in Teacher education, vol. 23, no. 2, pp. 30-35, 2001.

[24] Y. Gulbahar, "Teaching planning: a roadmap to successful technology integration in schools," Computers \& Education vol. 49, no. 4, pp 943-956, 2007.

[25] S. Hennessy, K. Ruthven, and S. Brindley, "Teacher perspectives on integrating ICT into subject teaching: Commitment, constraints, caution and change," Journal of Curriculum Studies, vol. 37, pp. $155-192,2005$.
N. Mndzebele achieved her bachelor of commerce, major in accounting in 1989, at University of Swaziland. In 1995, she got an MBA in calpoly in California, USA and Ph.D. in information systems in Ukzn South Africa 2012. She has been teaching since 1992 . 